\title{
THE IMPORTANCE OF SALT MINES FOR MINING TOWNS
}

\author{
Piotr LANGER \\ Cracow University of Technology, Faculty of Architecture, \\ Institute of City and Regional Design; ul. Warszawska 24, 30-155 Krakow, Poland; \\ e-mail:piotrlanger@pro.onet.pl
}

\begin{abstract}
Salt mining is one of the oldest industrial areas of human activity. Composure and evolution of rock salt mining methods were in the past an important factor of the development and prosperity of many European salt cities, including Wieliczka and Bochnia. Studies of Polish and foreign salt cities showed that urban space and underground mine workings can interact to varying degrees, often creating interdependent systems, both in economic and visually-compositional terms. At the same time, in the face of a global collapse of the salt mining industry, you can see the process of liquidation of underground salt mine, also a number of historical sites. The specificity of the salt mine also tends to post-industrial use of these facilities for new features. In this matter, the dominant course of action is to build underground tourist routes and sanatoriums, create places of a religious cult, art, entertainment, sports, science and education and other forms of public services. At the same time, salt excavations are an attractive area for the location of less accessible facilities, such as laboratories, and most of all underground deposits.

An analysis of different salt mining centres leads to the conclusion that all the mentioned forms of redevelopment can be cost-effective, however, to ensure the sustainable development of the salt mining centres it is important to:

- fully preserve the existing values, represented by both the excavation underground spaces as well as different parts of the surface mining infrastructure,

- expose and provide access to protected values for the broad group of users,

- maintain the authentic character of mine (excavation and ground facilities) in its reconstruction and adaptation to modern needs.

It seems that the inclusion of these conditions gives a real opportunity to preserve and even enhance the attractiveness of disused salt mines and use them in the current development of the salt cities.
\end{abstract}

Key words: unused salt mines, underground excavations, salt towns and regions, sustainable development, and cultural heritage 


\section{INTRODUCTION}

Underground mining can be recognized as one of the most important forms of industrial operations which is essential not only from a business point of view, but it also affects the development of towns, their spatial layout, structure, and urban landscape. In the past, the profits generated by mineral mining operations, including salt mining, gave the impetus for the placement of autonomous towns and guaranteed regular operation and development of towns.

Long-term co-existence of urban entities and underground mines, being integral parts of towns, caused the development of specific spatial layouts that operated on two levels: on the surface and underground. The elements of that system seem to be isolated, although they are actually interconnected and interdependent. That is expressed by the form and composition of the mining towns in which characteristic mining structures, especially the shaft complexes and headframes, as well as other elements are either closely or indirectly associated with the extraction operations. From the viewpoint of attractiveness and uniqueness of urban space, underground workings are the most important and integral parts of mining towns. They contain spaces with exceptional usability and viewing assets.

As a result of the restructuring projects applied to the mining sector, implemented by the end of the $20^{\text {th }}$ century, as well as other phenomena, underground mines lost their business importance in many European mining regions and they were mostly liquidated. In view of that process, the mine workings and surface extraction structures present serious economic and spatial problems. In the majority of cases, the liquidation of closed mines was associated with their removal from the urban landscape, which was justified in the light of economic and technical conditions, although it was equivalent to a irreversible loss of the values and qualities represented by the preserved mining structures.

The processes mentioned above concern the mining centres dedicated to the extraction of various minerals, especially coal and metal ores. They are also occurring in towns that have been traditionally associated with the underground extraction of rock salt, the industry representing long-term traditions and complex evolution paths.

\section{HISTORICAL ROLE OF SALT MINING IN THE DEVELOPMENT OF SETTLEMENT AND THE ORIGIN OF TOWNS}

Salt extraction is part of human history from the beginning of the industry's existence. Easy access to the mineral was a basic condition of human settlements and it was considered to be the foundation of the development of human civilization (Kurlansky 2004). The influence of salt mining on the development of towns was marked in the strongest way in the Middle Ages when primitive underground mines were established in Europe, allowing to start extraction of shallow salt beds. In those days, mining was one of the reasons for granting autonomy to towns, and it stimulated salt production centres. 
The location of the oldest Polish salt mining towns is dated in the Middle Ages: Bochnia (1253) and Wieliczka (1289).

Historical documents indicate that, during the whole period of salt mining town existence, salt mines were the centre points around which urban structures were growing and the social life of the residents was concentrating. In addition to mineral extraction, salt processing was an important factor of urban development. That branch contributed to the origin of Nowa Sól in Silesia, called Neusalz, in 1743, which the town was planned around a salt factory (Benysakiewicz red. 1993). Rock salt extraction on an industrial scale allowed to sell the production surplus and supply salt to the areas which suffered a shortage of salt. The salt trade stimulated the construction of roads which were transformed with time into main transportation routes (Międzybrodzka 2005) ${ }^{1}$. In addition to land routes, salt transportation was carried out on rivers to reach sea ports. That required the improvement of rivers and the construction of canals, landings, and salt warehouses which became points of urban development with time. One of such locations is Uście Solne, the town situated on the Vistula River, at the Raba River estuary, where a large salt storage area was operated in the Middle Ages, receiving the raw material extracted in the Bochnia Salt Mine (Wilk 1997) ${ }^{2}$.

The co-existence of urban centres and salt mines was symbiotic in nature. On the one hand, towns assured production workers, labour, and specialists, and, on the other hand, towns were becoming rich owing to salt trading. The income from salt mining operations was very significant, as confirmed by the words of the Papal Nuncio recorded in 1560: "The Polish King's income comes first of all from salt; he gets 106,000 talars a year after taxation. And he collects 52,000 talars in major customs duties [...]" (Hanik 1988).

The economic significance of salt mining was also indicated by the statement made by a Swiss scholar, Joachim Wadian, who reported on his stay in the Wieliczka Salt Mine at the end of the $15^{\text {th }}$ century: "From that huge treasury of Sarmatia, the ruler of that country draws larger income than many others could obtain from the richest gold and silver mines." The proceeds from salt sales made governments cover salt mining towns by special privileges causing that "[...] all types of crafts were flourishing and the residents were affluent" (Piestrak 1903). The care of the state consisted mainly in the planning and implementation of large capital investments allowing to increase the production efficiency and proceeds channelled to the government, as well as strengthening of the towns' defence capabilities, for example by the construction of city walls in the Middle Ages, or curtain-wall and bastion

\footnotetext{
${ }^{1}$ One of them was the salt route from Kraków to Wieliczka and the Orawa Region, across the Carpathian Mountains. A similar role was played by the "Prasołka" and "Via Regia," historical routes connecting the German towns of Lüneburg and Lübeck, as well as the "Alte Salzstrasse," the route running from the mining Town of Halle to Prague.

${ }^{2}$ An important salt port was also built in Kraków. It was located on the right hand side of the Vistula River bank, on the area of the present-day Zabłocie Borough. Salt produced in the Krakow's salt mines was shipped to the Baltic coast and farther by sea to various places in Europe. The Kraków river port has not survived until today, although a salt warehouse building still exists at $8 \mathrm{Na}$ Zjeździe Str. It was part of the old port facilities.
} 


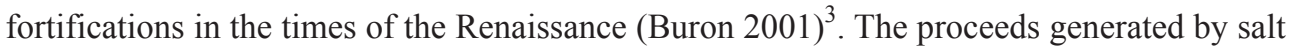
mining also allowed for the financing of important civil and urban engineering projects. King Casimir the Great was especially active in that area. Caring for the condition of the Kraków's salt mines, he decided to remodel the town of Bochnia, based on a new improvement plan, and also funded the town hall and one of the first miners' shelters in the world (Kiryk \& Ruta red. 1980). Also, the time of the dynamic development of Wieliczka matched the period of splendour of the local salt mine early in the $16^{\text {th }}$ century, when the town had two hospitals, a parish church, public baths, and a water supply system (Strzałkowski 2005). Owing to salt mining, Wieliczka could boast of its electricity network supplied from its own power plant. Bochnia obtained a modern telephone line connecting initially the Campi and Sutoris pitheads at the turn of the $20^{\text {th }}$ century.

The richness originating from the salt mines served not only the development of mining towns, but it also allowed for financing strategic national projects. The money generated by salt trade allowed King Sigismund the Old to remodel the Wawel Castle in the Renaissance style (Walczy 2007) and the archbishop of Salzburg to erect wonderful Baroque structures which give evidence to the beauty of the city until today, similarly to its salt mining past (Kurlansky 2004).

\section{ELEMENTS OF SALT MINING IN THE TOWN'S SPACE}

Salt extraction in underground salt mines causes not only the development of workings within the rock mass, but also of certain clear marks on the land surface, within the space of urban towns and their surroundings. Wherever the "external world" contacts the extraction working systems, we can usually find structural complexes situated close to shafts or drift entrances. The headframes, with their wheels, allowing for vertical transportation of people and minerals in shafts, have become recognizable elements of underground mines in both salt and ore mining ${ }^{4}$. Industrial operations of mines also require large backup facilities serving production and maintenance. The pithead structures also contain, in addition to transportation systems, office, maintenance, warehousing, and technical buildings, designed for preliminary salt processing, with mills or sorting plants for various rock chip fractions, as it is the case of the Kłodawa Salt Mine.

In addition to shaft structures, the salt towns contain a number of buildings whose functions are directly related to mining. They may often represent considerable historical, urban

\footnotetext{
${ }^{3}$ It is considered that the salt mine castles erected in Bochnia and Wieliczka are the examples of the first military structures built to ensure security of the industrial facilities and the local salt mines (Flasza 2005).

${ }^{4}$ Characteristic headframes appeared in the landscapes of mining regions only in the $19^{\text {th }}$ century when steam machines, followed by electrical ones, started to be applied. Such structures replaced horse-pulled tread mills situated inside specially designed pithead buildings. One of the last structures of that kind, with a tread mill, has been preserved in Prešov, Slovakia (Duchoň 2007).
} 
sight and composition values. A considerable sightseeing role is played within the urban space by the office buildings designed for salt mine managers. A representative nature has been preserved by the residences of high-ranking salt industry officials: villas with gardens, tenement houses, or large salt-mine castles. Also, some modest facilities were constructed within the salt mining towns. They were designed for lower-rank officers or regular workers, e.g. the mining estate in Gorzków near Bochnia (Flasza 2005).

Regular mining operations required the assurance of permanent labour, and that was associated with the need to carry out regular expansion and facilitation of the infrastructure accompanying the production facilities. Together with the development of mining functions, urban space was filled by a number of business premises, salt mills, barns, cart houses, and workshops and plants specializing in various types of crafts. Also, salt warehouses and storage facilities became essential components of urban structures. They were constructed in easily accessible locations, usually at main roads or in ports, and later close to railway stations. The necessity to transport salt from shafts to storages forced the implementation of special means of transportation. For example, the construction of a railway in the Bochnia Salt Mine in 1928 was an important project. The railway connected the Campi pithead with the railway station depot where a salt mill and storage yards were located. The new railway line replaced the overhead "cable railway" of a unique design.

Heaps of spoil banks or zuber constitute another spatial consequence of the industrial salt mining operations, well visible in the urban landscape. Their height often exceeds one hundred metres and the volume reaches millions of cubic metres. Owing to their sizes, heaps are the objects that are important for landscapes as they dominate in space and constitute conspicuous sight elements.

Salt mine operations contributed largely to the shaping of the urban public space systems, whose key elements included market places, squares, and salt trading streets, usually laid out close to mine shafts and surrounded by compact frontage structures ${ }^{5}$. The most important public spaces in salt mining towns also included park and garden areas, designed and executed since the second half of the $19^{\text {th }}$ century, usually by initiative of the mine management. Close to the parks, various office, business, and residential buildings were constructed, as required by the mine, and the green areas provided rest places for the residents and venues for open-air events.

The process of inclusion of various types of mining structures in urban space was developing throughout the centuries, strongly affecting the shape and form of urban systems. The elements associated with salt mine business operations were intermingled with urban structures, creating a single, strongly interconnected spatial system, with unique urban sight and composition qualities.

\footnotetext{
${ }^{5}$ Salt markets were also established in large cities which were not connected with salt production, such as Wrocław, Zamość, Lublin or Nysa, usually close to the main market square, as auxiliary trading yards, and that indicated the importance of salt trading in cities.
} 


\section{SPATIAL RELATIONSHIPS BETWEEN THE SALT MINE AND URBAN STRUCTURES}

Co-existence of two separate systems, surface development components and mine workings on the same area is an important feature of the underground salt mining centres. The historical growth of those apparently Isolated "worlds" depended on completely different factors. The directions of the spatial expansion of the underground workings were mainly decided by the geological conditions of salt beds, while the size and shape of towns depended primarily on land topography and the presence of such natural components as rivers, swamps, and forests, which limited the expansion of urban development. One may think, therefore, that the growth of the salt mine and of its town was quite independent. However, the analysis of available graphic materials indicates clearly that mutual interactions of the surface structure and the underground salt working systems were one of the main factors that decided about the directions and possibilities of spatial expansion of many salt towns, which can be followed for instance in Wieliczka and Bochnia.

The degree of interconnection between urban space and the underground mine sections is an individual feature of each town, and the mutual relationships of such components can be of a different complexity and intensity. In all salt mining centres, the shaft complexes or drift entrances are the points of direct contact between the surface and underground systems. Those points essentially influence the spatial expansion of both town and mine. Various models of salt mining towns, comprising the features of the town-mine spatial relationships, are placed in the table below (Tab. 1).

Table 1

Spatial relationships between the underground salt mine and urban development under various models of salt mining towns

\begin{tabular}{|l|l|c|c|}
\hline No. & Type of system & Situation & Cross-section \\
\hline 1. & integrated & parallel & \\
\hline 2. & &
\end{tabular}


Table 1 cont.

5.

The spatial systems of salt mining towns presented in Table 1 basically differ in respect of the relationships between the underground working systems and urban structures. We can notice that the models of the integrated and parallel systems are characterized by strong spatial mine-town relationships. They overlap on the plan and develop in correlation. Those models are typical for the majority of historical salt mines, which became the cores of strong urban centres in the past, such as Wieliczka and Bochnia, both involved in mining operations and salt trading. At the same time, the model of the isolated system shows that the two components can exist separately, without any close relationships. Such a system is characteristic for the salt towns of short mining history or for the urban centres in which salt mines were constructed and developed in difficult topographic conditions, e.g. in high mountain areas.

Some Polish salt mining towns, e.g. Kłodawa, Siedlec, and Moszczenica, as well as the Alpine salt towns of Hallstatt and Altausee, fulfil the isolated system model. Spatial relationships between the urban and underground-surface mining structures also decide about the strength and nature of mutual influences: their urban sight and composition significance, as well as the existence of mining menace affecting surface developments (Tab. 2). 
Table 2

The form and strength of mutual interaction between salt mining facilities and urban development under various mining-town models

\begin{tabular}{|c|c|c|c|c|c|c|c|}
\hline \multirow{2}{*}{ No. } & \multirow{2}{*}{$\begin{array}{c}\text { Type } \\
\text { of system }\end{array}$} & \multirow{2}{*}{$\begin{array}{l}\text { Locations } \\
\text { of shafts } \\
\text { in respect } \\
\text { of urban } \\
\text { structures }\end{array}$} & \multirow{2}{*}{$\begin{array}{l}\text { Surface mine } \\
\text { structures } \\
\text { and town } \\
\text { space } \\
\text { relationships }\end{array}$} & \multicolumn{3}{|c|}{$\begin{array}{l}\text { Sight and composition significance } \\
\text { of surface mining facilities }\end{array}$} & \multirow{2}{*}{$\begin{array}{l}\text { Influence } \\
\text { of mining } \\
\text { menace } \\
\text { on land } \\
\text { development }\end{array}$} \\
\hline & & & & $\begin{array}{c}\text { inside } \\
\text { town sight } \\
\text { relationships }\end{array}$ & $\begin{array}{l}\text { in } \\
\text { the town's } \\
\text { skyline }\end{array}$ & $\begin{array}{c}\text { in } \\
\text { the open } \\
\text { landscape }\end{array}$ & \\
\hline 1. & integrated & $\Delta \Delta \Delta$ & $\bullet$ & $\mathbf{m}$ & - & - & $\mathbf{m}$ \\
\hline 2. & parallel & $\Delta \Delta$ & • & - & $\mathbf{m}$ & - & m \\
\hline 3. & adjacent & $\Delta \Delta$ & $\bullet$ & - & $\mathbf{\square}$ & - & - \\
\hline 4. & neighbouring & $\Delta$ & 0 & - & - & $\mathbf{\square}$ & - \\
\hline 5. & isolated & $\Delta$ & 0 & 口 & 口 & $\mathbf{m}$ & घ \\
\hline \multicolumn{8}{|c|}{ 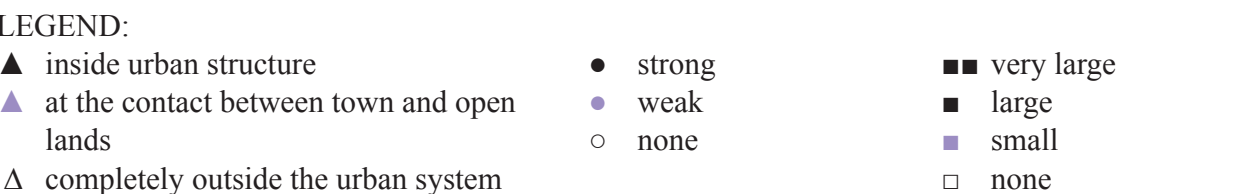 } \\
\hline
\end{tabular}

We can infer from the data presented in Table 2 that close spatial mine-town relationships are translated into large urban composition significance of the mining facilities, within the town's skyline and sight relationships inside the town. At the same time, the integrated and parallel models strongly display the detrimental mining menace effects visible in urban structures, including underground technical infrastructure. Then, in the models of loose town-mine relationships, mining facilities play a larger urban sight and composition role in the open landscape. Consequently, the negative influence of mining operations on land surface is lower.

Mutual relationships between diverse salt mine components and urban structures are of key importance for the present condition and the future of salt towns. They decide not only about a unique nature of urban space, but also about the options and optimum directions of salt mine use after completion of mining operations, as an impetus for the transformation of mining towns and their further development. 


\section{TRANSFORMATIONS OF SALT MINING AS AN IMPETUS FOR THE RESTORATION OF FORMER MINING TOWNS}

The statistical data indicate that the period of peak salt production, conducted by various methods, occurred in Poland, similarly to other European countries, in the 1980s. Afterwards, the output dropped significantly and it stays at a constant level in Poland, oscillating around 3.5 million tons a year, as clearly indicated by the data presented on Figure 1.

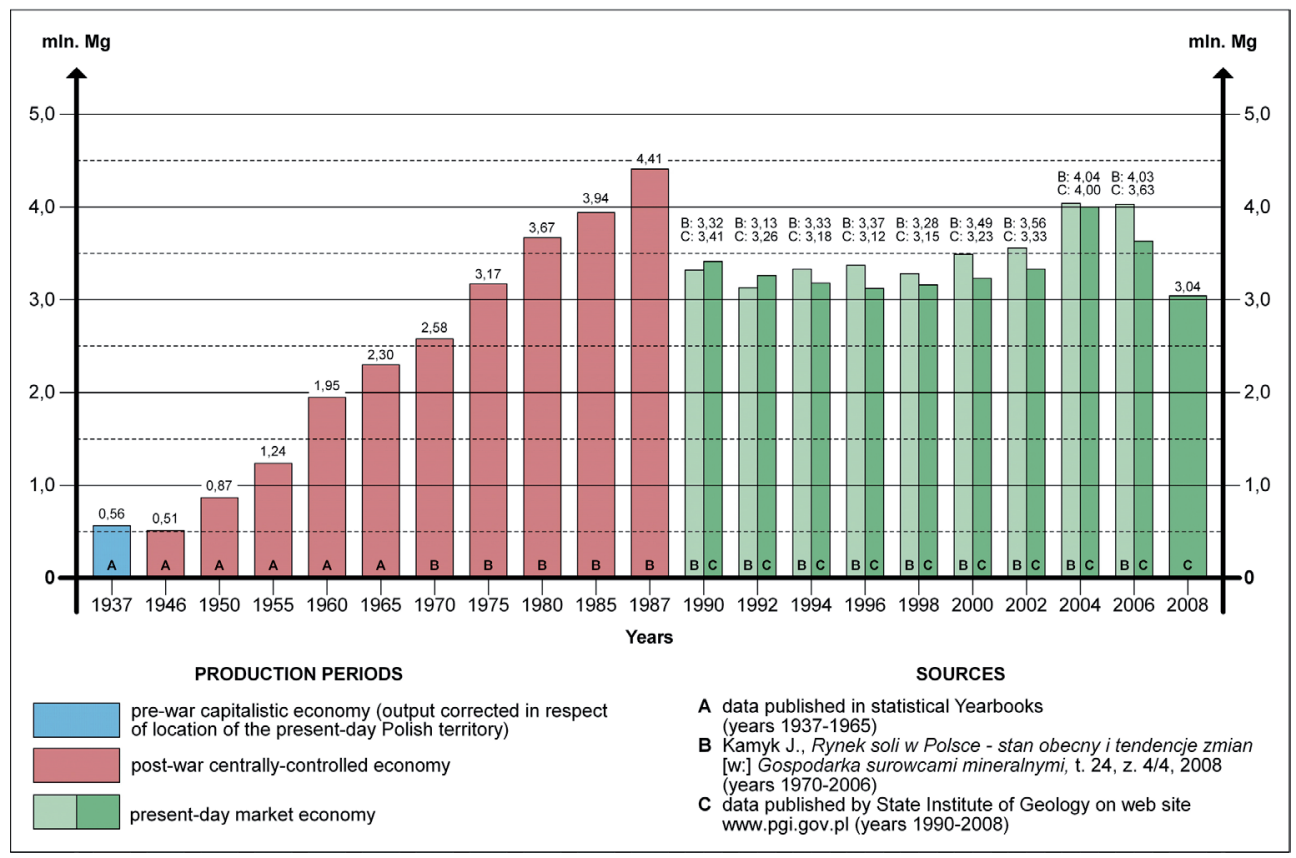

Fig. 1. Total salt output in Poland under various production methods, in 1937-2008. Sources: A: data for a period of 1937-1965 published in the Statistical Yearbooks (Roczniki statystyczne GUS), B: data for a period of 1970-2006 published in Kamyk (2008), C: data for a period of 1990-2008 published on the website of the Polish Geological Institute (www.pgi.gov.pl)

At the same time, the total production output shows a regular and proportional drop of salt quantity extracted by dry methods in underground mines, for the benefit of the raw material extracted by solution mining, on salt panes, and in desalination plants (Fig. 2). The causes of that process are complex. In addition to the development and growth of the competitiveness of modern salt extraction methods, mainly based on solution mining, the factors which cause limitation of the production by the dry method consists in the decreasing demand for rock salt in the solid form, a drop of the profitability of extraction resulting from huge salt mine maintenance costs, exhaustion of pure rock-salt deposits in small beds (especially in the case of the Miocene salt), and liquidation of unprofitable plants producing salt and other derived minerals, as well as mining menace and the real threat of disasters. 


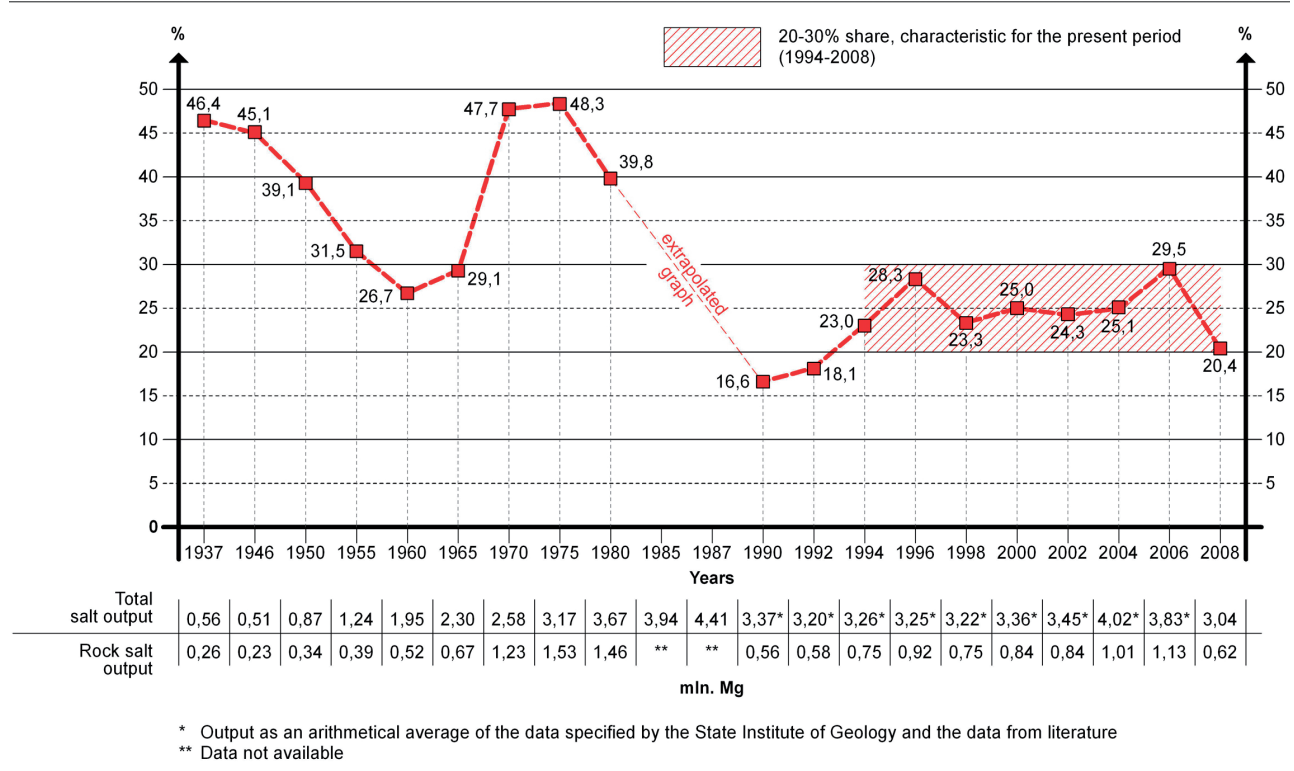

Fig. 2. The share of salt obtained by the dry method in underground mines in the total salt output in Poland in 1937-2008. Explanations: red slanted line area: 20-30\% share, characteristic for the present period (1994-2008); Table: Total salt output / Rock salt output.

Among about twenty salt beds recognized either primarily or in detail in Poland, only several are mined, including one exploited only periodically. Salt extraction by the traditional dry method is decreasing in importance for the national economy. In the post-war period, the majority of underground salt mines were closed and liquidated. The description of those salt mines operating in Poland in the post-war period is presented in the Table 3.

Table 3

General description of the underground salt mines existing in Poland in the post-war period

\begin{tabular}{|c|c|c|c|c|c|c|c|}
\hline No. & Salt mine & $\begin{array}{c}\text { Salt } \\
\text { mining } \\
\text { method }\end{array}$ & Mining period & $\begin{array}{c}\text { Present } \\
\text { status }\end{array}$ & $\begin{array}{c}\text { Main } \\
\text { causes } \\
\text { of closing }\end{array}$ & $\begin{array}{c}\text { Underground } \\
\text { working } \\
\text { condition }\end{array}$ & $\begin{array}{c}\text { Surface } \\
\text { infrastructure } \\
\text { condition }\end{array}$ \\
\hline 1. & Bochnia & $\square$ & $\begin{array}{c}\text { ca. } 1250-1990 \\
\text { (ca. 750 years })\end{array}$ & $\bullet$ & A, B, C & & $\nabla$ \\
\hline 2. & Wieliczka & $\begin{array}{c}\text { ca. } 1280-1996 \\
\text { (ca. } 720 \text { years) }\end{array}$ & $\bullet$ & A, B, C, E & $\diamond$ & $\nabla$ \\
\hline 3. & Wapno & $\square$ & $\begin{array}{c}1911-1977 \\
(66 \text { years })\end{array}$ & $\circ$ & D & $\diamond$ & $\Delta$ \\
\hline
\end{tabular}


Table 3 cont.

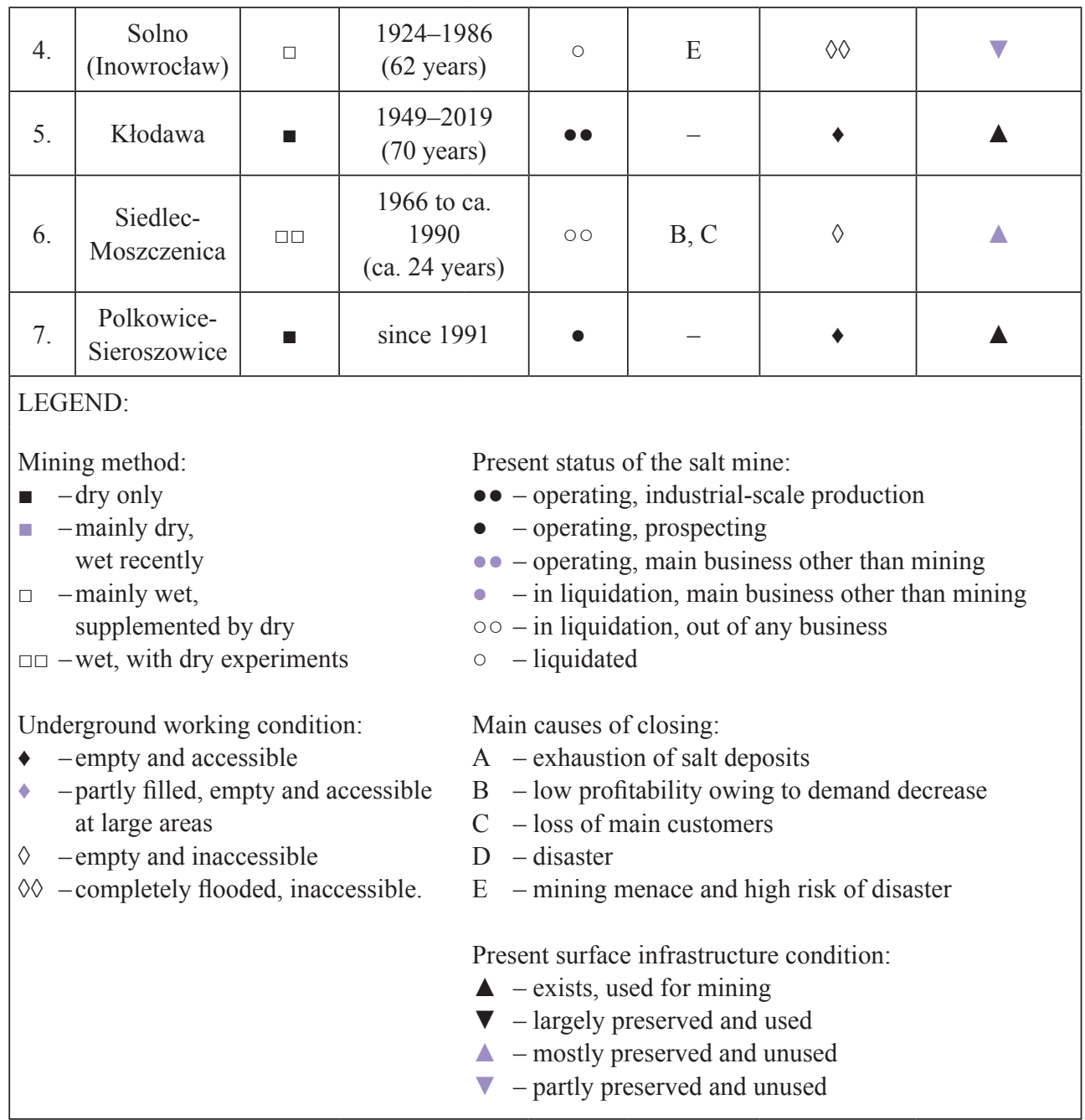

Based on the data presented in the Table above, we can conclude that, among all the underground salt mines operating in Poland after World War II, only two are still in the mining business: the Kłodawa Salt Mine and the Polkowice-Sieroszowice Salt Mine operating on the Kazimierzów field. We should mention, however, that the present concession of rock salt mining will expire in the Kłodawa Salt Mine in 2019, and one of possible scenario involves the discontinuation of industrial operations afterwards (Kunstman et al. 2005). The Polkowice-Sieroszowice Salt Mine owned by KGHM Polska Miedź (Polish Copper) is mainly involved in copper ore mining, and the Kazimierzów deposit is still 
in the recognition stage. It is not certain whether salt will be extracted there in the quantities to be mined on an industrial scale. The remaining salt mines, including all those associated with the Miocene deposit extraction, were closed down late in the 1990s. Only the two oldest Polish salt mines, Wieliczka and Bochnia, have been transformed into tourist and spa sites.

The phenomena mentioned above are the indications of gradual withdrawal from the dry mining method and recession of the traditional salt mining industry, observed not only in Poland. Similar facts are identified in Germany, for example in Lower Saxony, where the majority of underground salt mines extracting rock salt and potassium and magnesium salts were closed down in recent years (Fig. 3). Complete liquidation of rock and potassium salt mines Salzdetfurth in the spa town of Bad Salzdetfurth near Hildesheim is an example which illustrates that process. Despite attemepts at a post-industrial use of the faculities to be converted into the functions associated with spa treatment, the histgorical mine was not protected against destruction.

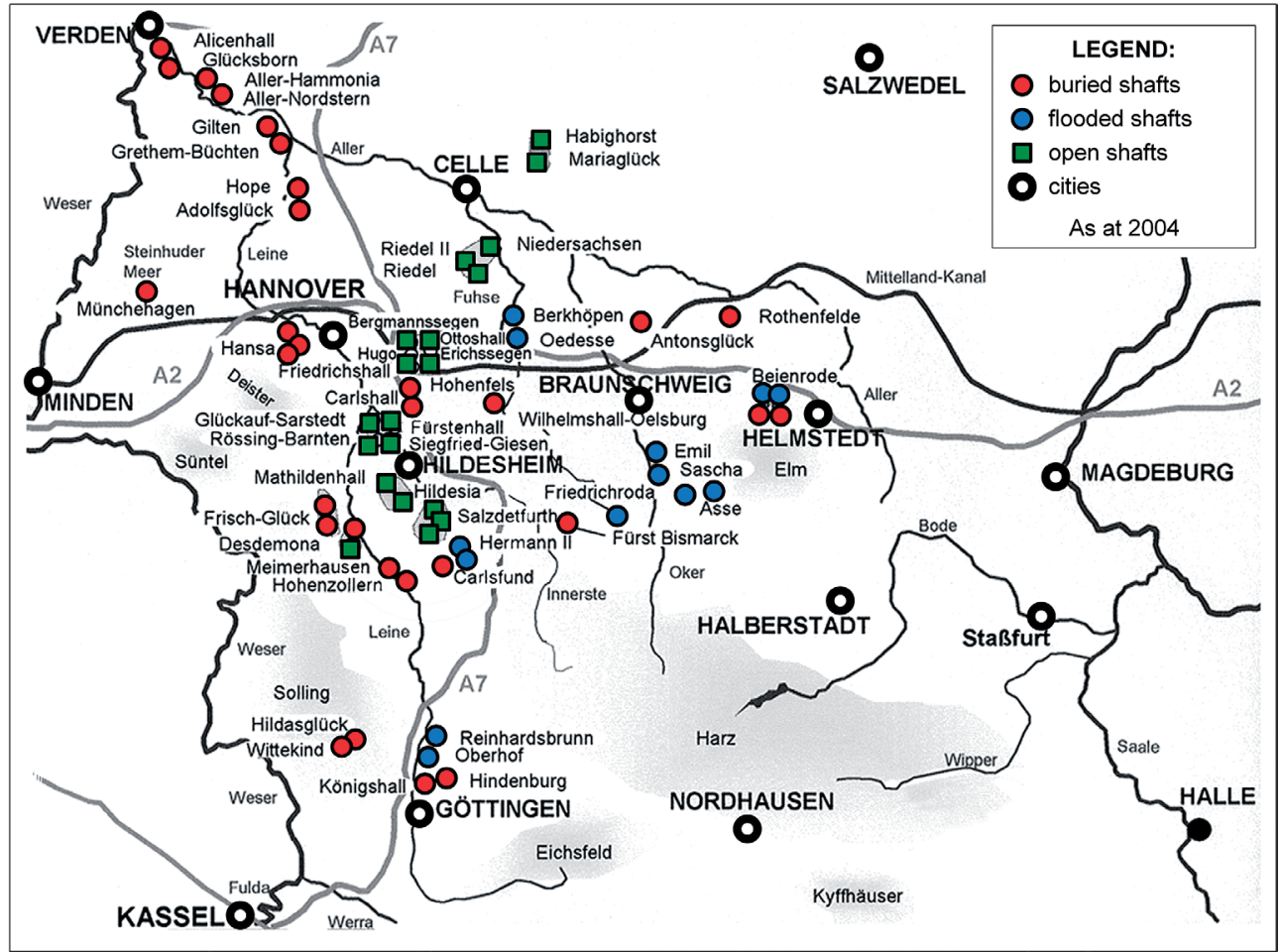

Fig. 3. The status of salt mines extracting rock salt and magnesium salts in Lower Saxony, Germany (author's study on the basis of materials presented by "Kali und Salz" Aktiongesellschaft-Inaktive Werke, made available by the Salzdetfurth Salt Mine management) 


\section{THE ROLE OF CLOSED SALT MINES IN THE PRESENT-DAY DEVELOPMENT OF MINING TOWNS}

The process of underground salt mine liquidation is usually associated with economic and technical conditions, bringing economic and social consequences. We should remember, however, that mine liquidation is associated with basic transformations of mining towns. undoubtedly, a positive aspect of mining stoppage is the limitation of mining menace, although each time a mine is closed, the town loses basic sources of income and it needs to determine a new vision for its development in which the preserved mining facilities can play various roles, if any.

Based on the Polish and international studies on the underground salt mining areas, we can conclude that, after a complete stoppage of mining operations, the salt mines are transformed under four different scenarios:

- "destructive" - with complete and irreversible liquidation of mines by filling or flooding of abandoned underground workings and demolition of the surface mining infrastructure;

- "indifferent" - with lack of decisive actions with respect to the underground workings and surface infrastructure after stoppage;

- "adaptative" - assuming a possibility of partial use of the closed salt mine by a functional adaptation of workings and of the selected surface facilities, in the direction which offers a chance to preserve and display the preserved assets, as well as ensure possibly complete access to the salt mine;

- "pseudo-adaptative" - associated with redesign and re-use of the closed salt mine in new operations, without assuming a need to preserve the mine qualities or full access to mining facilities in the post-industrial adaptation.

The collective description of the specific directions of the transformation of the liquidated underground salt mines, with the indication of the scope and spatial consequences of such transformations, is presented in Table 4.

\section{Table 4}

Collective presentation of the directions of transformations of closed-down salt mines, with the indication of the scope and spatial consequences of transformations

\begin{tabular}{|c|c|c|c|c|c|c|c|}
\hline \multirow[b]{2}{*}{ No. } & \multirow{2}{*}{$\begin{array}{l}\text { Direction } \\
\text { of transfor- } \\
\text { mation }\end{array}$} & \multicolumn{2}{|c|}{ Condition of } & \multirow{2}{*}{$\begin{array}{l}\text { Scope of use } \\
\text { of the closed- } \\
\text { down mine }\end{array}$} & \multirow{2}{*}{$\begin{array}{c}\text { Importance } \\
\text { of preserved } \\
\text { values }\end{array}$} & \multirow{2}{*}{$\begin{array}{l}\text { Acces- } \\
\text { sibility }\end{array}$} & \multirow{2}{*}{$\begin{array}{c}\text { Influence } \\
\text { of transfor- } \\
\text { mation on } \\
\text { the town space }\end{array}$} \\
\hline & & workings & $\begin{array}{l}\text { surface } \\
\text { facilities }\end{array}$ & & & & \\
\hline 1. & "destructive" & $\boldsymbol{\Delta}$ & $\Delta$ & - & - & $\bullet$ & negative \\
\hline 2. & "indifferent" & $\Delta$ & $\boldsymbol{\Delta}$ & - & - & - & negative \\
\hline
\end{tabular}


Table 4 cont.

\begin{tabular}{|c|c|c|c|c|c|c|c|}
\hline \multirow[b]{2}{*}{ No. } & \multirow{2}{*}{$\begin{array}{l}\text { Direction } \\
\text { of transfor- } \\
\text { mation }\end{array}$} & \multicolumn{2}{|c|}{ Condition of } & \multirow{2}{*}{$\begin{array}{l}\text { Scope of use } \\
\text { of the closed- } \\
\text { down mine }\end{array}$} & \multirow{2}{*}{$\begin{array}{l}\text { Importance } \\
\text { of preserved } \\
\text { values }\end{array}$} & \multirow[b]{2}{*}{$\begin{array}{l}\text { Acces- } \\
\text { sibility }\end{array}$} & \multirow{2}{*}{$\begin{array}{c}\text { Influence } \\
\text { of transfor- } \\
\text { mation on } \\
\text { the town space }\end{array}$} \\
\hline & & workings & $\begin{array}{c}\text { surface } \\
\text { facilities }\end{array}$ & & & & \\
\hline 3. & "adaptative" & $\Delta$ & $\boldsymbol{\Delta}$ & - & - & - & positive \\
\hline 4. & $\begin{array}{l}\text { "pseudo- } \\
\text { adaptative" }\end{array}$ & $\boldsymbol{\Delta}$ & $\boldsymbol{\Delta}$ & - & घ & $\bullet$ & negative \\
\hline \multicolumn{2}{|c|}{ LEGEND: } & \multicolumn{2}{|c|}{$\begin{array}{l}\Delta \text { not preserved } \\
\Delta \text { preserved }\end{array}$} & $\begin{array}{l}\text { none } \\
\text { adaptation }\end{array}$ & $\begin{array}{l}\text { none } \\
\text { large }\end{array}$ & $\begin{array}{l}\text { - none } \\
\text { - little } \\
\text { - large }\end{array}$ & \\
\hline
\end{tabular}

The data presented in Table 4 indicate that the specific directions of the transformations of closed-down salt mines cause different spatial consequences and they are of completely different importance for the shaping the salt mining towns, as post-industrial centres.

"Destructive" operations, often justified by economic or other objective circumstances, assume the liquidation of the mine under a planned, physical demolishing project applied to the mine as a composition of diverse assets, together with its specific values and qualities. The essence of liquidation usually consists in conducting comprehensive activities, which include filling of workings and demolition of surface facilities, either in whole or a large part. Any unused facilities, including characteristic headframes and auxiliary facilities are subjected to demolition, even those which represent historical continuity and often significant urban architectural, sight, and composition values. The removal of post-mining installations is justified as those are not usable for any other functions after stopping the mining operations, although at the same time, the process causes the loss of integral and important components of urban space. After the completion of the liquidation process, the reclaimed land of the former salt mine plant is usually surrendered to the town authorities and released for new public or private projects, implemented without any reference to the former and traditional land management methods. Omitting the social aspects here, e.g. increase of the local unemployment rate, liquidation of the salt mine under the "destructive" process contributes to a significant loss of the salt town's identity and durable and harmful change of its specific nature.

The "destructive" approach, although it exerts a definitely negative impact on the salt town space, is presently the most often seen a direction in salt mine liquidation transformations. That process can be observed in the majority of European countries in which salt mining was subjected to deep transformation processes for various reasons. A good example of that is the Solno Salt Mine of Inowrocław in Poland. We can assume that, owing to real threat of mining menace, the planned liquidation of underground workings was justified and unavoidable there. Moreover, the removal of surface salt mine facilities, without an attempt at their re-use and display as important parts of the historical cultural heritage seems to be a negative conception.

Under the "indifferent" approach, in contrast to the "destructive" one, immediate destruction of the preserved post-mining heritage is not the case. Under that type of salt-mine 
liquidation processes, certain facilities are preserved, especially the pithead complexes with headframes. However, in the majority of cases, no attempts at redesigning or functional adaptation of those facilities are made. Unused buildings and engineering installations preserve temporarily their urban sight and composition values, although a long-term lack of proper adaptation and preservation works leads to imminent technical degradation of structures, causing that they cannot be used in any way in the future. Consequently, ruined mining facilities must be demolished. Such a situation can be observed for example in Wapno and Moszczenica, recently retired Polish mining centres, as well as in former salt mining centres abroad: Ukrainian Kalush and Stebnik (Fig. 4), or German Bad Salzdetfurth.

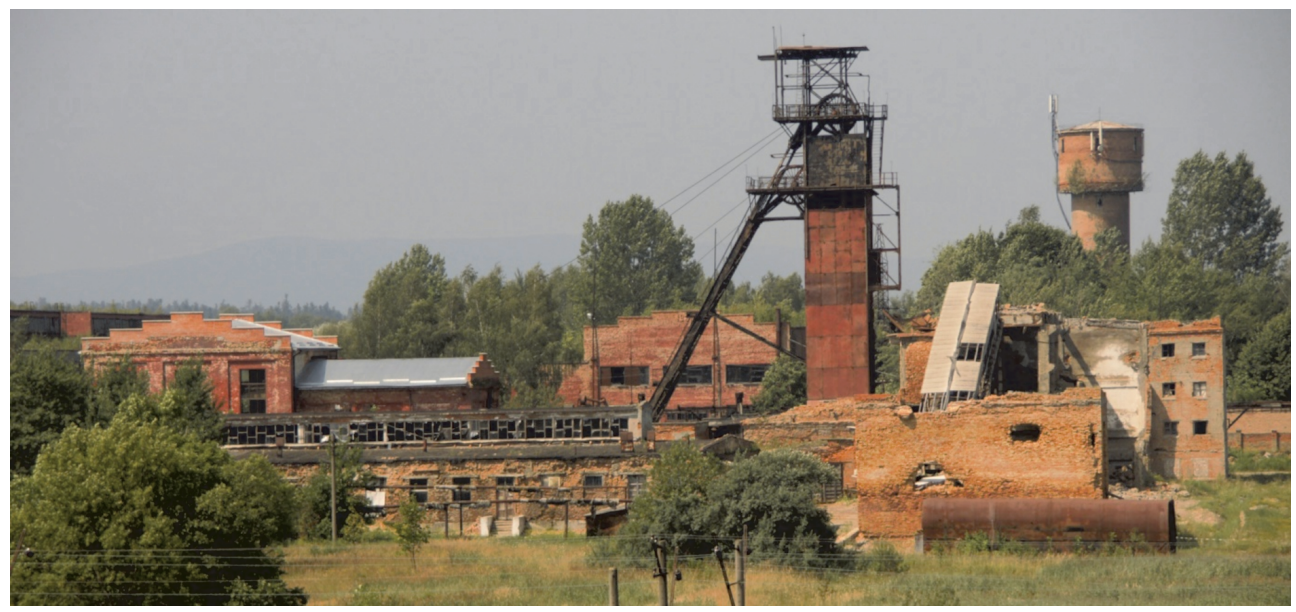

Fig. 4. Ruined and useless post-mining facilities in Stebnik, Ukraine, the relics of a liquidated salt mine

When appraising the spatial consequences that are characteristic for the "indifferent" process, we should say that they are analogous to those associated with the "destructive" process, although they occur with some delay. The "indifferent" approach should be recognized to be very unfavourable from the viewpoint of shaping the salt mine space, identity or attractiveness. Idle presence of inactive salt mines brings a double loss to towns. On the one hand, the deteriorating mining facilities create a negative image of urban space, and on the other hand, a lack of an idea for adaptation and use of inactive salt mines for other purposes reduces the town's offerings where a revitalized salt mine could play an important or even a key role.

From the viewpoint of salt mining town development programming in a post-industrial period, the largest importance is attached to the "adaptative" approach. It assumes full use of the preserved mining facilities: underground workings, surface infrastructure, and land. The essence of that direction consists in the functional adaptation of unused salt mines, with the protection of specific mining heritage assets and display of preserved qualities by making the salt mine available as a post-industrial site for as many groups of users as possible. 
The fulfilment of those conditions offers a chance to maintain the historical identity of urban space and the increase the town's attractiveness. Consequently, the process opens a possibility of stable and long-term economic growth.

Numerous examples of the re-use of inactive salt mines, equipped with new and attractive functions, demonstrate that even after retirement the salina facilities can remain important components of city landscape. Many post-industrial salt towns have been successfully using the preserved salt workings and surface structures, with the creation of attractive public spaces offering unconventional functions and unique sight-seeing values. Such components are not only taken into account in the present-day urban revival projects, but they also become the main engines of such projects. That is reflected in planning documents and salt mine development strategies in which adapted salt mines determine the principles and directions of town refurbishment under long-term prospects.

Owing to considerable values and unique features, the abandoned underground salt workings can be adjusted to various functions. The most important of them is tourism, spa treatment clinics based on halotherapy (Ponikowska 2004, Kmiecik 2006, 2007, Chervinskaya 2007, 2009), mass and qualified sports, recreation, museums, religious activities, education and science (Czapowski et. al. 2004), as well as art, culture, and entertainment ${ }^{6}$. The experiences of many European salt-mining towns indicate that the process of functional adaptation can successfully involve surface facilities, supplementing rich service offerings provided by mine workings. Examples of such a direction of activities can be seen in Bochnia and Wieliczka, the historical salt mines of the old "Kraków Salt Mining Region." A similar function is fulfilled by the Alpine towns located in the area of Salzburg: Halstatt, Berchtesgaden, Hallein, and Altaussee, or even more recent facilities of the German Salt Mine in Merkers (Figs 5, 6).

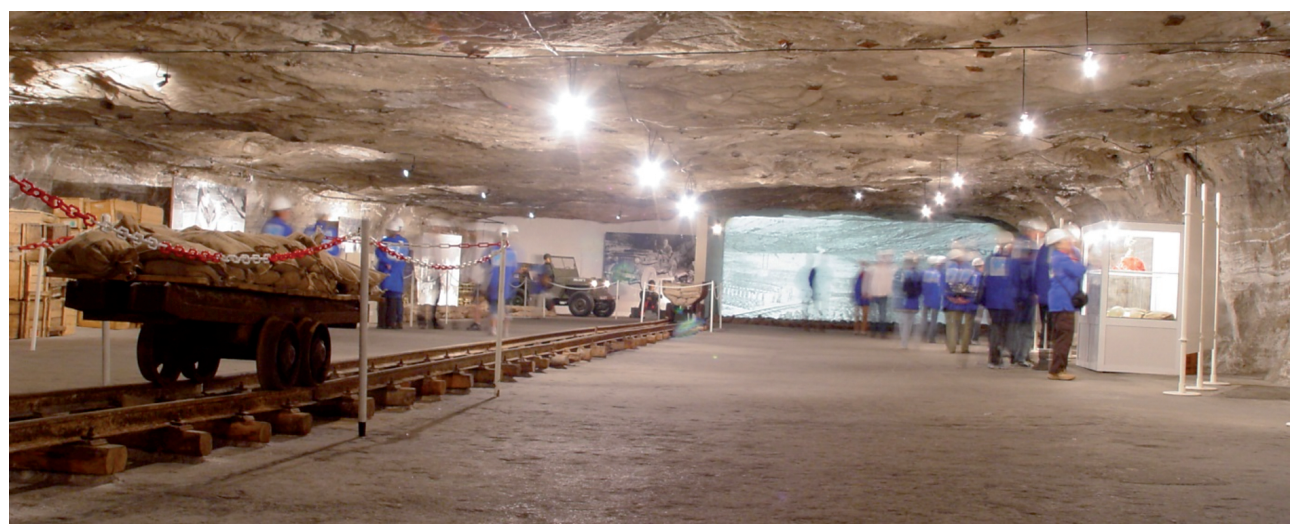

Fig. 5. Salt mine workings in Merkers, Germany, adapted for tourist and museum purposes

${ }^{6}$ The author is writing about the directions of present-day adaptations of closed salt mines, giving the factors which decide about the possibilities of using salt workings for specific functions, in his study entitled Salt Workings as Urban Spaces (Langer 2012). 
Absolutely unique among adapted salt mines are two Romanian facilities in Turda and Slanic. The first one is operating as an entertainment and recreation centre, with an underground lake and various attractive installations for sports and games. The Slanic Salt Mine is enchanting with its scale and forms of workings dug out in solid salt rocks, with one of them changed into an underground cathedral.

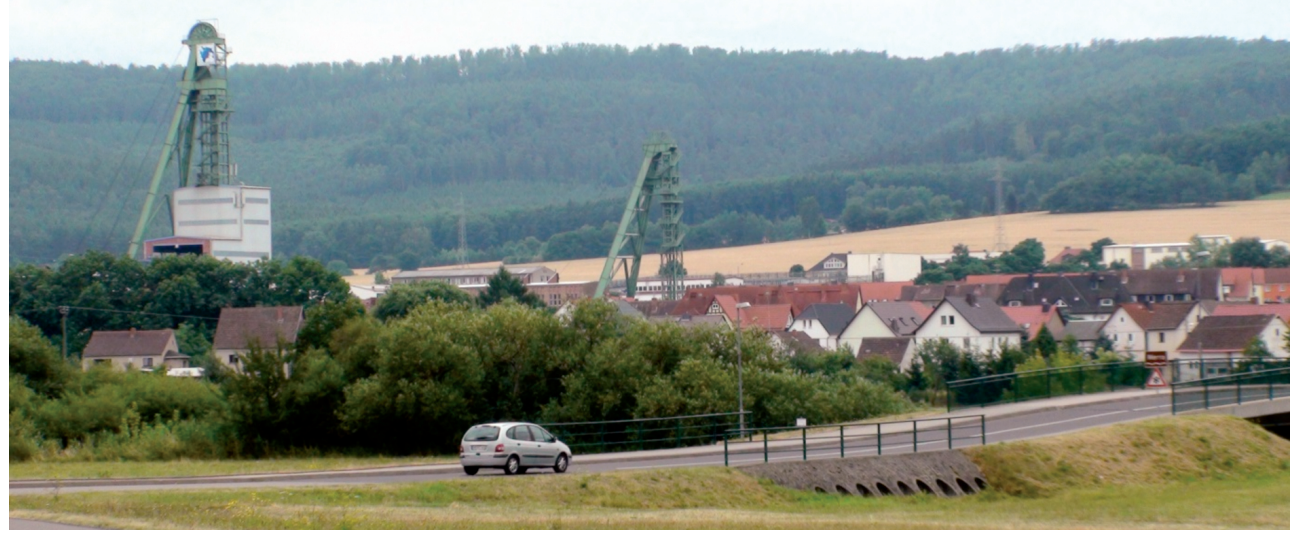

Fig. 6. Merkers, Germany, characteristic salt-mine headframes, dominating the urban space. Preserved pithead facilities are used for post-industrial activities conducted within salt-mine workings

The last of the characteristic types of transformations applied to the liquidated salt mines is called "pseudo-adaptative." Similarly to the "adaptative" process, it assumes reuse of salt-mine workings and surface plant. The basic difference between both processes concerns the method of using the preserved assets and the scope of making them available as post-industrial facilities. The "pseudo-adaptative" method of using a liquidated salt mine usually consists in a functional adaptation, for example for underground storages or warehouses, including depositories for toxic materials and radioactive waste (Brańka 2005, Marx et al. 2005, Makhnach et al. 2009), as well as the placement of advanced research laboratories in the underground workings (Markiewicz et al. 2006). The implementation of such functions does not have to mean any destruction of the assets available in the workings, although in each case, it is associated with the restriction of access to the former salt mine, without displaying the preserved cultural heritage. Besides, the transformation of the salt-mine workings into waste depositaries is essentially a planned form of complete liquidation of the industrial space, with a serious limitation of concurrent use for any other purposes. Such a situation can be observed in the German Sondershausen Salt Mine which, besides the tourist functions, also works as a waste storage site. We should mention the fact that the active storage area is one of the most important facilities on the underground tourist route. However, the workings will be completely filled one day and they will not be available any more. 
Although the transformation of the salt-mine under a "pseudo-adaptative" method can be economically profitable, it constitutes a serious threat to the cultural values created by the mining function, and it cannot be a basis for a long-term development of the respective salt-mining town.

When describing various ways of present-day transformation and the use of former salt mines, we should also mention the activities which can be called "restoration" projects. That direction is of marginal importance presently, and as yet, it is fairly theoretical. It basically consists in the reinstatement of the values lost as a result of planned salt-mine liquidation or unpredicted events, e.g. mining disasters. The "restoration" method can involve making the underground workings available, after filling or flooding, as well as the reinstatement of the original or changed extraction infrastructure, after demolition or dismantling of such assets during the salt mine liquidation project. The main assumption of the restoration process is primarily present-day use of the regained salt mine for public purposes, with the display of specific assets to increase the attractiveness of urban space. Most certainly, a serious obstacle for "restoration" operations can be presented by large resources required for the project and some technical problems. However, we need to emphasize that the restoration of a salt mine is feasible also in Polish conditions. Such activities are getting more and more important, as indicated by the recent discussions about the restoration possibilities of the Solno Salt Mine of Inowrocław, flooded for safety reasons in 1986. Flooding was assumed to be durable and irreversible at that time. Restoration of that unique plant seems to be unrealistic, but despite that, the project was positively evaluated by the regional government and theoretically it qualifies for applying for the resources from the EU structural funds.

\section{SUMMARY AND CONCLUSIONS}

The issues presented in this paper clearly indicate a direct relationship between salt mining and historical and current development, as well as the spatial shaping of salt-mining towns. Presently, special importance is attached in salt-mining centres to the activities designed for dealing with the underground mines which have been closed or are planned to be closed.

The Polish and European experiences demonstrate that the dominating direction of the old salt mine transformation involves either "destructive" operations or an "indifferent" attitude, which lead to the loss of specific cultural heritage of mining towns, harming the towns' attractiveness and identity, and forcing people to look for new grounds for development, based on the functions that are detached from local traditions.

At the same time, we can quote a number of towns in which attempts were made at postindustrial use of old salt mines for new purposes by remodelling and functional adaptation of underground workings and diverse surface facilities. Among a whole range of the possibilities to re-use post-mining structures, we can indicate the "adaptative" and "pseudoadaptative" methods which differ basically in respect of the display of assets and general access to the remodelled salt mines. At this point, we should emphasize strongly that only 
the "adaptative" direction complies with the Polish constitutional principle of sustainable development, under which it is required to preserve the balance between economic growth and the need to protect cultural heritage for present and future generations. It seems that the "adaptative" actions especially influence former mining centres where we can observe strong relationships between urban structures and both underground and surface mining facilities. In such cases, current transformations of abandoned salt mines can be of fundamental importance for the future development of the respective towns and the quality and attractiveness of urban spaces.

When analyzing the condition of preservation and use of salt mines after the completion of business operations, we can conclude that, for the protection and later re-use of the preserved elements of post-mining heritage, it is of essential importance to the start redesign and adaptation of salt mines even during the stage of mine liquidation. That would allow people to avoid expensive and difficult restoration projects meant for the physical recreation of lost assets, although without bringing back the genuine nature of salt mines as industrial plants.

\section{REFERENCES}

Benyskiewicz J. red., 1993. Nowa Sól. Dzieje miasta. Zielonogórskie Zakłady Graficzne, Zielona Góra.

Brańka S., 2005. Specyfika i możliwości budowy podziemnych magazynów w złożach soli w Polsce. X Międzynarodowe Sympozjum Solne Quo Vadis Sal - Przyszłość podziemnego magazynowania w złożach soli, Ciechocinek 13.10.2005-14.10.2005, 10-14.

Buron G., 2001. Bretagne des Marais Salants. Skol Vreizh, Morlaix.

Chervinskaya A., 2007. Haloterapia w mikroklimacie komory solnej jako metoda medycyny rekonwalescencyjnej. Balneologia Polska, 49, 2(108), 142-144.

Czapowski G., Sadowski A., Misiek G. \& Kolonko P., 2004. Możliwości niekonwencjonalnego wykorzystania walorów przyrodniczych i technicznych Kopalni Soli Kłodawa. IX Międzynarodowe Sympozjum Solne Quo Vadis Sal - Racjonalne sposoby wykorzystania złóż solnych, Bochnia 25.11.2004-26.11.2004, 28-30.

Duchoň M., 2007. Potulky po sol’nej bani. Ateliér Jana, Prešov.

Flasza J., 2005. Bochnia. Przewodnik po mieście. Urząd Miejski w Bochni, Bochnia.

Hanik M., 1988. Wieliczka-siedem wieków polskiej soli. Interpress, Warszawa.

Kamyk J., 2008. Rynek soli w Polsce - stan obecny i tendencje zmian. Gospodarka Surowcami Mineralnymi, 24, 4/4, 143-154.

Kiryk F. \& Ruta Z. red., 1980. Bochnia. Dzieje miasta i regionu. Urząd Miejski Miasta Bochni, Kraków.

Kmiecik M., 2006. Subterraneoterapia w Kopalni Soli „Wieliczka”. Część 1. Balneologia Polska, 48, 1, 68-70.

Kmiecik M., 2007. Subterraneoterapia w Kopalni Soli „Wieliczka”. Niecodzienność metody i miejsca. Część 2. Balneologia Polska, 49, 1(107), 64-67. 
Kunstman A., Poborska-Młynarska K., Lepiarz J. \& Urbańczyk K., 2005. Wstępne koncepcje likwidacji Kopalni Soli „Kłodawa” na podstawie doświadczeń górnictwa solnego. X Międzynarodowe Sympozjum Solne Quo Vadis Sal - Przyszłość podziemnego magazynowania $w$ złożach soli, Ciechocinek 13.10.2005-14.10.2005, 61-63.

Kurlansky M., 2004. Dzieje soli. Książka i Wiedza, Warszawa.

Langer P., 2011. Znaczenie specyfiki dziedzictwa kulturowego miast solnych dla ich tożsamości i współczesnego rozwoju, ze szczególnym uwzględnieniem Bochni. Kraków [Ph.D. thesis].

Langer P., 2012. Wyrobiska solne jako przestrzeń urbanistyczna. Geology, Geophysics \& Environment, 38, 2, 239-250.

Markiewicz A., Pytel W. \& Zalewska A., 2006. Koncepcja wybudowania Laboratorium Polskiej Fizyki Cząstek w złożu najstarszej soli kamiennej na terenie LGOM. XI Międzynarodowe Sympozjum Solne Quo Vadis Sal - Pokładowe złoża soli w Polsce, Szklarska Poręba, 9.11.2006-10.11.2006, 49-53.

Międzybrodzka M., 2005. Solne trakty Rzeczypospolitej - katalog wystawy. Muzeum Żup Krakowskich, Wieliczka.

Państwowy Instytut Geologiczny, [on-line:] www.pgi.gov.pl [access: December 2013].

Piestrak F., 1903. Kilka słów o Wieliczce i jej kopalniach z ilustracyami Jana Czarneckiego. W. Kornecki, Kraków.

Ponikowska I., 2004. Przegląd balneologicznych metod leczniczych. Medycyna Rodzinna, $3,117-118$.

Ponikowska I., 2009. Tradycja, nowoczesność i innowacyjność w lecznictwie uzdrowiskowym naszych czasów. XVIII Kongres Uzdrowisk Polskich - Innowacyjne kierunki rozwoju turystyki uzdrowiskowej i lecznictwa uzdrowiskowego, Muszyna, 4-6 VI 2009, Stowarzyszenie Gmin Uzdrowiskowych RP, Krynica-Zdrój, 15-21.

Roczniki statystyczne GUS - lata 1937-1965.

Strzałkowski P., 2005. Zarys rozwoju technologii górnictwa podziemnego. Wydawnictwo Politechniki Śląskiej, Gliwice.

Walczy Ł., 2007. Rola żup krakowskich w finansowaniu przebudowy rezydencji królewskiej na Wawelu. [in:] Jodłowski A. (red.), Studia i materiały do dziejów żup solnych w Polsce, 25, Muzeum Żup Krakowskich, Wieliczka, 115-152.

Wilk J., 1997. My z soli i roli, czyli Uście Solne w XX wieku: wspomnienia. Poligrafia Inspektoratu Księży Salezjanów, Uście Solne.

\section{Streszczenie}

Górnictwo solne jest jedną z najstarszych dziedzin przemysłowej działalności człowieka (Hwałek 1971, Kurlansky 2004). Opanowanie górniczych metod eksploatowania złóż soli kamiennej, a następnie ich wielowiekowa ewolucja były w przeszłości istotnym czynnikiem miastotwórczym, przyczyniając się do powstania i rozkwitu wielu europejskich miast solnych, w tym historycznych ośrodków w Polsce - Wieliczki i Bochni (Hanik 1988). 
Prowadzone przez autora badania polskich i zagranicznych miast solnych wykazały, że przestrzeń miejska i podziemne wyrobiska kopalni mogą na siebie oddziaływać w różnym stopniu, tworząc niejednokrotnie układy silnie powiązane (Tab. 1, 2), zarówno w znaczeniu ekonomicznym, jak i widokowo-kompozycyjnym (Langer 2011). Jednocześnie zjawiska obserwowane w wielu europejskich regionach górnictwa solnego wskazują na spadek znaczenia tego sektora przemysłu (Fig. 1), a ponadto na malejący udział soli kamiennej eksploatowanej metodą suchą w ogólnym bilansie produkcji (Fig. 2). W obliczu tych tendencji nasila się proces likwidacji podziemnych kopalni soli, również wielu obiektów historycznych (Tab. 3, Fig. 3). Likwidacja kopalni soli oraz związane z nią przekształcenia podziemnych i naziemnych obiektów poprzemysłowych mogą mieć istotne znaczenie dla współczesnego rozwoju ośrodków górniczych.

Jak wynika z prowadzonych przez autora badań terenowych, przekształcenia nieczynnych kopalni soli mogą przebiegać w różnych kierunkach, powodując zróżnicowane skutki dla przestrzeni miast górniczych (Tab. 4). Najczęściej proces likwidacyjny polega na trwałym i całkowitym wypełnieniu przestrzeni poeksploatacyjnych, obejmuje również rozbiórkę infrastruktury naziemnej lub pozostawienie obiektów pogórniczych bez użytkowania, co wiąże się z nieodwracalną degradacją dziedzictwa kulturowego (Fig. 4). Specyfika kopalni soli skłania także do poprzemysłowego wykorzystania tych obiektów i ich przystosowania do pełnienia nowych funkcji. Dominującym kierunkiem działań w tym zakresie jest budowa podziemnych tras turystycznych i sanatoriów (Chervinskaya 2007, Ponikowska 2009), tworzenie miejsc związanych z kultem religijnym, sztuką, rozrywką, sportem, nauką i edukacją (Czapowski et al. 2004) oraz innymi formami usług ogólnodostępnych (Fig. 5). Równocześnie wyrobiska solne stanowią atrakcyjną przestrzeń dla lokalizacji mniej dostępnych obiektów, takich jak laboratoria badawcze (Markiewicz et al. 2006), a przede wszystkim podziemne składowiska i magazyny (Brańka 2005).

Analiza różnych ośrodków górnictwa solnego pozwala stwierdzić, że wszystkie formy poprzemysłowego zagospodarowania wyrobisk solnych mogą być opłacalne ekonomicznie, jednak dla zapewnienia zrównoważonego rozwoju górniczych ośrodków salinarnych istotne jest dążenie do pełnego zachowania istniejących wartości - reprezentowanych zarówno przez podziemne wyrobiska, jak i zróżnicowane elementy infrastruktury powierzchniowej, a także eksponowanie i udostępnienie chronionych wartości dla możliwie dużej grupy użytkowników-odbiorców. Wydaje się, że uwzględnienie powyższych warunków daje realną szansę zachowania, a nawet wzmocnienia atrakcyjności nieczynnych kopalni soli oraz wykorzystania ich w obecnym i przyszłym rozwoju miast solnych jako ośrodków poprzemysłowych. 